\title{
Business and State Balancing International Development Agendas - The Case of Norwegian CSR
}

\author{
Anne Welle-Strand ${ }^{1} \&$ Monica Vlaicu ${ }^{1}$ \\ ${ }^{1}$ BI Norwegian Business School, Norway \\ Correspondence: Anne Welle-Strand, BI Norwegian Business School, Nydalsveien 37, 0484 Oslo, Norway. Tel: \\ 474-641-0765. E-mail: anne.welle-strand@bi.no
}

Received: July 21, 2013 Accepted: August 2, 2013 Online Published: August 30, 2013

doi:10.5539/jpl.v6n3p103 URL: http://dx.doi.org/10.5539/jpl.v6n3p103

\begin{abstract}
This study looks into the interplay between governments and transnational corporations (TNCs) regarding corporate social responsibility (CSR), and it investigates the potentials to link CSR to the international development agenda. The analysis focuses on Norwegian CSR, that illustrates a rare combination of strong state with significant ownership in national companies, a relatively small number of TNCs and a strong civil society. The results of the analysis indicate that the Norwegian government exercises a strong influence over corporate governance. However, despite an apparent alignment between the topics proposed by the State's development cooperation agenda and those Norwegian companies are expected to report on, the analysis did not find proof of a transfer of agendas. Instead, businesses appear to use CSR as a communication tool, thus complying with the government's desire to project a positive image of Norway internationally. Furthermore, the government appears to prioritize commercial goals and profitability.
\end{abstract}

Keywords: corporate social responsibility, development, Norway, ownership, regulation, transnational corporations

\section{Introduction}

Norway's involvement in international development efforts has earned it a disproportionate amount of influence relative to its economic size. Similarly, Norwegian companies are renowned for their exemplary social and environmental practices. The core values embedded in the fabric of Norwegian society appear to be the upheld both in the State's development cooperation policies and in corporate governance. In recent years the political discourse has become such in relation to the business sector's role in development, that one is persuaded to wonder how the interplay between the different spheres - public and private, non-profit and for profit - may influence the international development agenda.

This study evolved from two principal observations, namely visibly stronger state involvement in corporate social responsibility (CSR), and a shift from primarily state overseen international development agendas to a growing number of development-oriented initiatives by transnational corporations (TNCs). Several features recommend Norway as a fitting candidate for this paper's analysis. First, despite being a relatively small country located in a remote geographical area, Norway plays a large role in international development debates. Economic affluence, international aspirations and a strong 'Christian missionary zeal' have imbued the Norwegian mindset with a sense of responsibility to 'do good' (Welle-Strand et al, 2009). Furthermore, official development assistance is concentrated on areas of perceived Norwegian expertise - human rights, peace efforts, clean energy and the environment. This has earned Norway a positive image as international donor that the government seems eager to strengthen, not least through CSR.

Compared to other Western countries, and even its Scandinavian neighbours, Norway has few, but large TNCs. Moreover, they are concentrated in a small number of key industries such as the energy sector, finance, or telecommunications. Additionally, the State has significant ownership in many of these TNCs. The industrial and the ownership concentration have fostered an environment of intense scrutiny by civil society actors (the media in particular) and there is a huge amount of pressure for Norwegian TNCs to behave responsibly (Alm, 2007). Thus, both the government and the companies have embraced the concept of corporate social responsibility early on. Due to the extensive mandate of the Norwegian welfare state, Norwegian CSR policies have mainly addressed corporate activities abroad, especially in developing countries (Albareda et al 2008; Gjølberg, 2010). 
Hence, the objective of this study is to discuss whether there has been a shift in governmental and corporate practices in Norway, while exploring to what extent the expectations towards TNCs role for development has changed. The preliminary assumption is that strong state influence might lead to state owned TNCs allowing certain areas of corporate responsibility to take precedence over others.

The first section of this article frames the analysis by exploring the notion of CSR in the context of globalization. The following section looks into the case for and against CSR as a tool for international development. Next, the translation of CSR in Norway is presented, and the role of state ownership and the interplay between state and state owned companies is underscored. The importance of state ownership for Norwegian CSR is then analysed. Finally, implications for future research are explored.

\section{CSR in a Globalized World}

Globalization and the 'retreat of the state' have resulted in opportunities for TNCs to exercise functions traditionally attributed to nation-states (Detomasi, 2007; Kobrin, 2009; Matten \& Crane, 2005; Strange, 1996). Notably, the last decade has seen a mounting campaign for TNCs to act unequivocally towards furthering international development, with CSR representing a focal point of these discussions (Blowfield, 2005, 2007; Jenkins, 2005; Frynas, 2005, 2008; Margolis \& Walsh, 2003; OECD, 2007; Vogel, 2005). Although continually contested and open for interpretations, CSR has without doubt become an item of mainstream debates. CSR represents a contemporary reaction to long lasting demands to bridge the gap between business practices and the values and expectations of society (Carroll, 1999; Davis, 1973; Friedman, 1970; Matten \& Moon, 2008). With globalization it has diversified into a staggering number of variants, crossing borders and infiltrating the mainstream agenda of governments, TNCs, international organizations and civil society actors (Carroll, 1999). CSR seems thus not only prone to transformation, but inviting it, having to maintain its flexibility in order to be relevant in different cultural settings (Donaldson, 1996). Nevertheless, the multitude of CSR interpretations and practices is criticised as masking a lack of genuine progress, "as it becomes increasingly difficult to measure progress without an identified objective” (Okoye, 2009:215). This is a valid concern given the efforts to integrate CSR into more comprehensive and effective frameworks for international development.

Initially CSR was propelled by values stemming from an Anglo-American historical and philosophical acquis (Mele, 2008; Okoye, 2009). In Europe the concept grew from the liberalization wave of the late 1970s and 1980s, which had made companies de facto socially responsible as they took over many areas of public goods provision (Newell \& Frynas, 2007). More recently, actors from developing and emerging countries have also begun adding their perspectives to our understanding of corporate responsibility (Baskin, 2006; Chapple \& Moon, 2005; Ghazali, 2007; Li \& Zhang, 2010). The growing popularity of corporate responsibility during the last decade coincides with the deepening sense of living in a transitioning world system described as a post-Westphalian order (Kobrin, 2009) or post-national constellation (Habermas, 2001). The main features of this current system - the decline of state power, the proliferation of problems transcending national borders and jurisdictions, an unprecedented pluralism of values and cultural heterogeneity (Donaldson, 1996; Kobrin, 2009; Habermas, 2001; Strange, 1996) - have enabled growing involvement and sway of TNCs in political debates (Detomasi, 2007; Kobrin, 2009; Matten \& Crane, 2005; Schrerer \& Palazzo, 2007, 2011; Vogel, 2005). These features have made their mark on the nature and focus of the CSR debate.

The concept of business responsibility was originally understood primarily in relation to the domestic market within which companies operated (Davis, 1973; Friedman, 1970). Investment in local welfare represented a means of securing better educated, more skilled and healthier workers, but also reflected a company's stronger identification with and ties to the local community (Davis, 1973). TNCs today operate in a space where there is no single state power defining or enforcing the rules of the games and where corporate activities unfold in multiple cultural and institutional contexts (Matten \& Crane, 2005). In their recent review on new CSR perspectives Schrerer and Palazzo (2011) advocate for a politicised understanding of corporate social responsibility. Starting from the new premises of globalization and the post-national constellation, they criticise the limits of the instrumental approach to CSR. They argue that the three basic premises of the economic view on CSR - the explicit separation between economic and political spheres; profit making as the prime responsibility of any corporation (Friedman, 1970; Henderson, 2001); and social responsibility being conditional on the value it adds to a company (Waddock \& Graves, 1997) - are no longer valid in the current setting.

Political CSR "goes beyond the instrumental view on politics in order to develop a new understanding of global politics where private actors such as corporations and civil society organizations play an active role in the democratic regulation and control of market transactions" (Schrerer \& Palazzo, 2011:901). This understanding makes room for new deliberations on the limits of responsibility (Schrerer \& Palazzo, 2011), the costs of 
responsible behaviour (Vogel, 2005), the roles assumed until now by stakeholders in their interaction with corporations and how these roles can change for CSR to improve. States represent powerful stakeholders and Western governments have become active drivers of CSR (Albareda et al, 2008). Today public policies not only endorse and facilitate it, but also allow the government to mandate and partner with companies in an effort to address specific issues (Fox et al, 2002). Some studies suggest that companies themselves consider the government's role as stakeholder, but especially as regulator, important for improving CSR performances of the majority of companies (Gjølberg, 2011). Today, with TNCs and governments acting and interacting both as political and as economic players, the relationship between state and corporations is as important as it has ever been.

\section{TNCs and Development: A Role for CSR?}

Since the turn of the millennium there has been renewed emphasis on the role of the business sector for poverty alleviation and sustainable development (OECD, 2007). Climate change, international migration, poverty and conflicts are interconnected at the global level and thus beyond the reach of traditional government authority and control (Kobrin, 2009; Strange, 1996). Given the global nature of their organization and their economic clout it has been argued that TNCs have the ability to address many of these problems (OECD, 2007). Thus, CSR may be engineered into an effective tool for social and economic development. Certainly this seems to be the sentiment of some Western governments, including the Norwegian one, who are promoting CSR as a direct method of engaging businesses in the development processes of poor countries.

The current enthusiasm for CSR goes beyond viewing it as a way to mitigate the negative externalities of international business activities (Blowfield, 2005). Expectations are that CSR should contribute to development by bringing entrepreneurial-type solutions to poverty, education and health, among other problems. Despite the ambiguous results of CSR programs in terms of promoting development (Blowfield, 2007; Frynas, 2005, 2008), a consensus seems to have already been reached - companies should adopt responsibility codes and give back to society, in one way or another. This eagerness to become involved often bypasses the process of determining what works, and under which conditions and so far "CSR has not explicitly dealt with the poverty impact of business activity” (Jenkins, 2005:528).

A sizeable literature has emerged detailing this caveat and exploring the potential and limitations of CSR for development (Blowfield, 2005, 2007; Frynas, 2005, 2008; Jenkins, 2005; Margolis \& Walsh, 2003; Newell \& Frynas, 2007). Both TNCs' commercial activities and their CSR policies can be linked to improvements in development (Blowfield, 2007; Frynas, 2005, 2008; Newell \& Frynas, 2007). Some maintain that, in general, CSR's contribution to social and economic issues will always be smaller than that of direct investment, taxes and employment (Newell \& Frynas, 2007). Furthermore, the direct and immediate consequences of a company's operations can be measured in economic terms and thus quantified, while value transfers and long term implications of any particular CSR program are difficult to assess (Frynas, 2005, 2008). Even when results are tracked systematically, the long run effects of implementing a CSR program are difficult to monitor, especially for value-based objectives. Companies seem therefore inclined to limit their reports to quantifiable aspects of their short-term impact, which further strengthens the focus on the economic approach to CSR.

There has been criticism of the progress or lack thereof achieved by CSR in development. Company CSR programs have been proven to "work for some firms, in some places, in tackling some issues, some of the time" (Newell \& Frynas, 2007). Furthermore, the issue of the development goals pursued through the means of CSR has also been a point of contention in recent debates. Western governments, corporations and civil society actors have found some common denominators for responsible behaviour - the respect of human rights and the environment, fighting corruption. However, some argue that the development priorities identified by developing countries themselves might not coincide with those chosen by Western actors (Newell \& Frynas, 2007; Vogel, 2005). Many point out that CSR has been almost entirely defined by values and rights stemming from a capitalist mindset (Blowfield, 2005; Margolis \& Walsh, 2003; Schrerer \& Palazzo, 2011). It is argued that "the world of CSR would look very differently if the priorities of the poorer groups were put first" (Newell \& Frynas, 2007:678). The instrumental approach to CSR fails to incorporate the values and interests of stakeholders which do not have the power to make a difference in company profits (Mitchell et al, 1997). While Western non-governmental organizations (NGOs) and governments eagerly draft policies for CSR, the stakeholders businesses interact with directly are the governments and peoples of the developing countries where they operate (Newell \& Frynas, 2007). The CSR debate is still unequal in that it concentrates on the contributions of a restricted number of actors (Western businesses, governments, NGOs), while marginalizing others. However, unless businesses are willing to invest in developing regions there can be no discussion about their contribution to the development of those areas. 


\section{CSR in the Norwegian Context}

As previously mentioned, Norway's social, economic and political structures are uniquely situated for the study of the interaction between government and TNCs.

For a start, civil society actors in Norway - labour unions, the media, and non-governmental organizations (NGOs) - are particularly vocal, both in development cooperation and CSR discussions (Alm, 2007; De Geer et al, 2009; Midttun, 2005). They exert significant pressure on Norwegian TNCs to adopt specific codes of conduct in foreign operations. The Norwegian media's critique of business practices is based principally on ethical considerations, in particular with regards to human rights and the environment (Alm, 2007; Welle-Strand, 2008). More often than not, media reports exclude practical and financial considerations altogether, insisting instead on the companies' obligation to uphold Norwegian values and principles abroad. Whether positive or negative, the media coverage reflects a normative view of what good business practices should be. For instance, after a wave of criticism toward the Norwegian Government Pension Fund Global (GPFG) which prompted the GPFG to adopt new criteria for its investment, many articles began presenting the fund's ethics guidelines as a unique and exemplary model to be emulated internationally (Alm, 2007). The media and NGOs continue to play a role in the ongoing scrutiny of GPFG's investment portfolio.

Also characteristic of the actors in Norwegian civil society is the unclear line between private and public identities, and between for-profit and non-profit activities of organizations, both in the field of development assistance and in debates surrounding CSR. An underlying assumption in most countries is that companies, NGOs and unions represent independent organizations i.e. "for-profit or non-profit [entities] that have been created for some purpose other than the administration and enforcement of government policy" (Pearce et al, 2009:506). In Norway, organizational independence ought to be strictly scrutinised, since funding can often be traced back to the government (Figure 1).

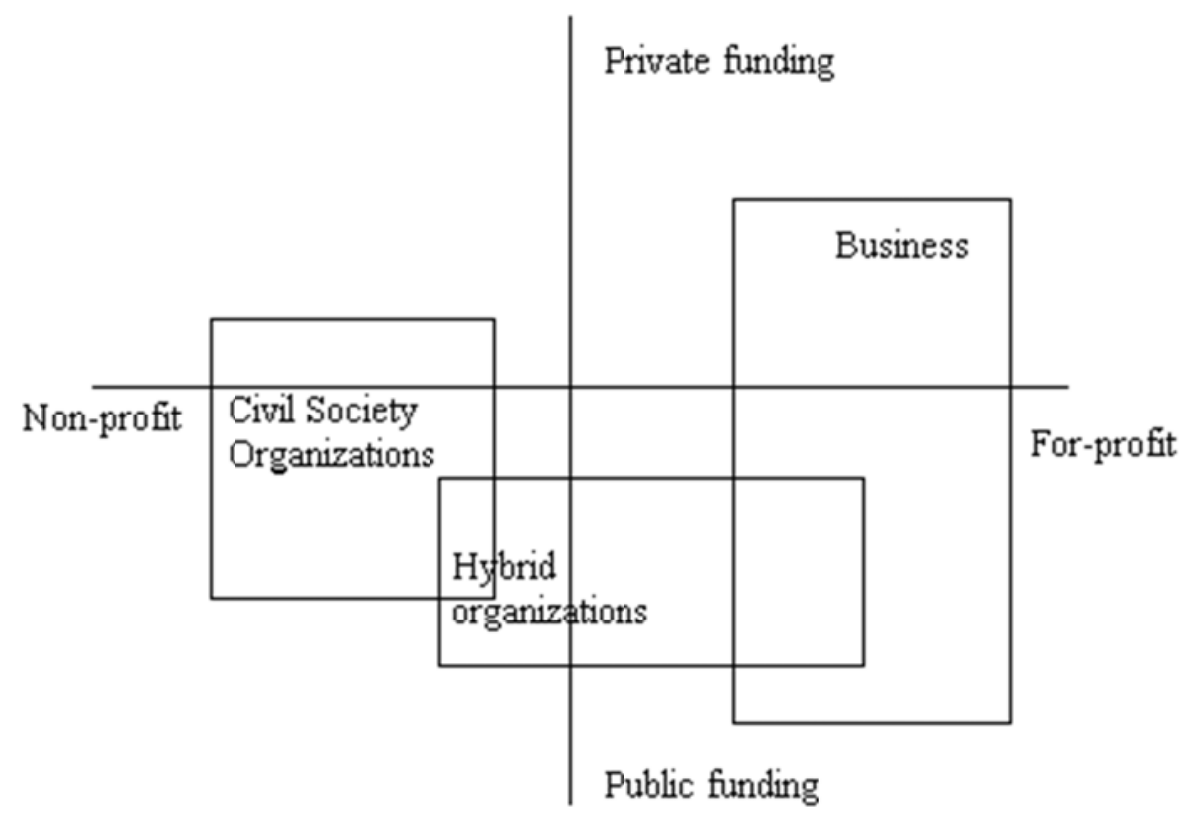

Figure 1. Actors in Norwegian CSR and development cooperation

The space between for-profit and non-profit activities has been bridged by the emergence of hybrid organizations of different natures such as investment funds (e.g. Norfund), venture philanthropists, or private individuals (Welle-Strand et al, 2009). Therefore, companies, civil society actors and hybrid organizations are seemingly competing with each other in developing countries and in debates over development, ethics and responsibility. Nonetheless, the interests behind their agendas are unclear and could potentially trace back via their funding sources to a common denominator - the State.

The Norwegian state has historically been a "legitimate problem solver" and is expected to act through the means of the large public sector in order to secure the common good (Olsen, 1996). Furthermore, the public agenda has been explicitly constructed to integrate organised interest groups into public policy and functions 
using a consensual approach to problem solving. Therefore public reforms have been notoriously slow and their scope limited, earning Norway the reputation of "a turtle" in terms of capacity to adapt and change the status quo (Ibid.). In terms of CSR, even more than in other Nordic countries, the powerful Norwegian labour unions have been heavily involved in public policy, curtailing the influence of corporations over societal issues (De Geer et al, 2009; Gjølberg, 2010). As a result Norwegian companies were largely excluded from the welfare processes (Olsen, 1996; Gjølberg, 2010; Midttun, 2005) and before liberalization began the great majority of Norwegian corporations, concentrated in a small number of industries with few major players, were state owned.

Today Norway is home to a total of 27 state-owned TNCs, representing 4.1 percent of total state-owned TNCs world wide (UNCTAD, 2011). The Norwegian state remains the largest investor on the Oslo stock exchange, owning 37.5 percent of the total share value in 2011. The five largest domestic companies listed on the Norwegian stock market - Statoil, Telenor, DNB, Yara International and Norsk Hydro - have a significant degree of state ownership (Table 1). These companies are also among the best rated in terms of corporate responsibility in the world.

Table 1. Norwegian TNCs with significant state ownership

\begin{tabular}{ccccc}
\hline $\begin{array}{c}\text { Listed } \\
\text { Companies }\end{array}$ & Main Sector of Activity & Market Value & $\begin{array}{c}\text { Stock Market } \\
\text { Share }\end{array}$ & State Holding \\
\hline Statoil & Oil & 489457 & $37.4 \%$ & $67 \%$ \\
Telenor & Telecommunications & 157764 & $12.05 \%$ & $54 \%$ \\
DNB & Banking & 95366 & $7.3 \%$ & $34 \%$ \\
Yara International & Agriculture (fertilizer & 69037 & $5.27 \%$ & $36.2 \%$ \\
industry) & Aluminium, Energy & 57394 & $4.4 \%$ & $34.3 \%$ \\
\hline
\end{tabular}

Source: Norwegian Government 2012; Norwegian Stock Exchange Statistics 2012.

The Norwegian government first laid down a comprehensive strategy for CSR in 1998 by establishing the Consultative Body for Human Rights and Norwegian Economic Involvement Abroad (KOMpakt). Meant to be a forum for dialogue between "the human rights community, the private sector and the Norwegian authorities" (White Paper, 1999), KOMpakt illustrated the mistrust in business conduct abroad, especially in countries with poor records of human rights. It also displayed a clear non-domestic focus of the Norwegian CSR agenda as understood and promoted by the authorities, illustrating their desire to use CSR in furthering Norway's international standing as a peace and human rights champion (Albareda et al 2008; Gjølberg, 2010). In pace with the changes at international level, KOMpakt has since been re-branded as "the consultative body for CSR" which has gradually moved towards embracing an economic approach to CSR balancing this against the focus on humanitarian issues (Gjølberg, 2010).

The Norwegian Ministry of Foreign Affairs then delivered the 2009 White Paper concerning governmental expectations in terms of companies' CSR practices. This document described the transfer of humanitarian values, good employment and anti-corruption practices as means of promoting development. The 2009 White Paper on CSR was strongly criticised by civil society as "lacking ambition", "missing vision" or being "inadequate" (Ramos, 2010). One of the main points brought up was that the government had failed to take the opportunity of putting in place concrete strategies to ensure companies' compliance to Norwegian CSR practices. This represents a recurrent demand from civil society organizations that envision a stricter framework for CSR, with less emphasis on business voluntary action and more legal requirements. However, what is disconcerting is that such demands ignore the serious matter of evaluating and improving the content of the CSR agenda (Jenkins, 2005). While the case has been made against business values and interests controlling the CSR agenda (Blowfield, 2005), there is no reason why not to be sceptical of a similar 'monopoly on values' imposed by any other stakeholder in the name of the greater common good. As Porter and Kramer (2006:82) noted "the vehemence of a stakeholder group does not necessarily signify the importance of an issue - either to the company or to the world”. Considering Norway's record of poor evaluation, follow up of results and learning from change (Olsen, 1996), the normative side of the Norwegian CSR agenda seems all the more problematic. 
Coming back again to the societal role attributed to Norwegian companies, it must be underlined that unlike in the Anglo-American culture where entrepreneurship and financial success is rewarded, profit seeking was traditionally not well perceived by the public and the media. Therefore, in the Norwegian context the concept of CSR had to transform in order to be credible and to do so it took on much of the discourse observed previously in the welfare system. Looking into Norwegian companies' website reporting (Yara, Norsk Hydro, Telenor, Statoil), recurring topics include human rights, labour standards, and gender equality (e.g. the number of women in the organization). Furthermore, irrespective of the sector in which they operate, other common subjects for CSR reporting are environmental responsibility ("green banking" - DNB), corruption and, more recently, the positive impact of simply doing business. While the former illustrate a continuation into CSR of the welfare and ethical traditions, reporting on the virtues of doing business demonstrates the shift in approaches that has taken place in Norway since the early 2000s.

Within the Norwegian development assistance circles the dominant opinion that businesses are uniquely profit driven (Amland, 1993) has been gradually replaced by the public-private cooperation discourse. As of the 2000s the Norwegian government's development cooperation policy began to dedicate more space to the role of the business sector for economic growth and development (White Paper, 2009b). TNCs' business-as-usual actions are now considered to be catalysts for economic growth by kick-starting a chain of productive activities, generating employment and paying taxes. Corporate responsibility has also shifted from a dominant rights-based, normative approach to a win-win concept within the sustainable development strategy, justifiable economically (Albareda et al, 2008; Gjølberg, 2010). Website data now commonly informs on a company's tax activities, the number of its employees, and their diversity (Yara, Telenor). Some companies even take it upon themselves to document the economic and social impact of their CSR initiatives. For instance, the Norwegian telecom operator Telenor commissioned several independent reports assessing the social and economic impact of their main programs (Telenor website). These quantitative analyses help to enhance the credibility of a company's claims to responsibility, more than auditing aimed solely at value-transfer could.

Besides the hard evidence such data provides, its also plays into companies' natural strengths and interests, A survey of corporate governance in Scandinavian countries found that reputation, branding and competitiveness were key reasons for companies' engagement in CSR (Gjølberg, 2011). It seems that Nordic countries in general are eager to make CSR practices more widespread globally. This may be a consequence of companies meeting strong competition from less ethical corporations elsewhere, as most companies were in favour of stronger government regulation in order to improve the results of CSR initiatives. Paradoxically, Norwegian companies appear less competitive than their Nordic counterparts that boast similar good records of corporate governance. In 2011 Norway ranked as the $16^{\text {th }}$ most competitive economy in the world, behind most of its Nordic neighbours, with lower scores in terms of industrial competitiveness, particularly in innovation and sophistication (WEF, 2011). At a first glance it would seem that when combining competitiveness with social welfare, the government and the business sector have yet to find the optimal formula, although poorer competitiveness is not necessarily a result of strong ethical regulations.

CSR appears to fit squarely in the government's strategy to promote international development through the mix of business-government-international agencies efforts. However, the results have been debated, and the concern for the TNCs' competitiveness has been posed. CSR is most often considered valuable to the competitiveness of a corporation if the home-market has a strong consensus on the importance of CSR initiatives. The dilemma arises when Norwegian companies operating abroad face societies where corruption, weak governance and poor labour rights are present. The Norwegian government promoting more investment from Norwegian TNC's in such areas may leave the companies more exposed to the risk of betraying CSR commitments.

In sum, CSR is constantly changing and adapting to different settings (Donaldson, 1996). The diffuse meaning of CSR poses a risk since progress is not easily evident from solely the evolution of the debate on CSR itself. In Norway this is challenging because the country has a history of slow reforms associated with little follow-up or implementation of changes. Nonetheless, the Norwegian government and TNCs have been early adopters of CSR and there seems to be a link between public and private CSR policies. Nevertheless, the motivation of Norwegian companies projecting strong CSR profiles is still to appear socially responsible. Influence from the state level makes Norwegian companies subject to scrutiny if they fail to comply with the expectations.

\section{State Influence or Interference?}

Traditionally, states have been the main actors in the international system. This understanding represents the main pillar of the realist school of international relations, where state interactions define the system, and all states act on behalf of their interests alone. In such a setting development aid represents an extension of the state's foreign policy, a means for achieving greater influence and other political or economic goals (Jackson \& 
Sørensen, 2003). While most private companies would have no place in this system per se, state owned companies could be pictured as extensions of state power. This is plausible even in the context of globalization and the decline of state power (Matten \& Moon, 2008). In Norway, the government does not seem inclined to accept the 'retreat of the state' thesis and is considerably active both in the welfare sphere and in the business sector (White Paper, 2006, 2009c, 2011). Thus the Norwegian CSR public policy can be viewed as an additional step by government to integrate businesses into the wider development cooperation agenda. This is particularly evident through the policies of the current social-democratic Norwegian government.

The importance of the state owned sector has been underplayed in the wake of the liberalization wave of the 1980s and 1990s. However, although less than 1 percent of TNCs worldwide are state owned, they represent an important global force (UNCTAD, 2011). An analysis of Norwegian companies' FDI revealed that state owned enterprises (SOEs) were "less reluctant than [privately owned enterprises] to invest in countries with poor institutional business climates” i.e. rule of law, property rights and corruption (Knutsen et al's, 2011). It would seem that because of the dual role of the state as owner and as stakeholder it is likely that SOEs' investment decisions are linked to non-economic goals such as foreign policy or foreign aid (Ibid.). The government's policy for CSR and its policies for development cooperation bear striking resemblance in that the areas they choose to focus on are largely intertwined.

Norway's development cooperation centres around five main priority areas for action: climate change and environment; peace building, human rights and humanitarian assistance; women and gender equality; oil and clean energy; good governance and the fight against corruption (White Paper, 2009b). These are the same element recognised as important in the CSR White Paper (White Paper, 2009a). This overlap may not be coincidental. One way to view this alignment is as a piece of a larger puzzle, namely of "the marketing project seeking to brand Norway as a 'humanitarian superpower'” (Gjølberg, 2010:213). Government reports hint to the role Norwegian businesses are expected to play in furthering specific foreign policy goals, not least in the area of development.

Current Norwegian development cooperation explicitly underlines the interdependence between governments and businesses in promoting development (White Paper, 2009b). The partnership of private and public approaches for development is an already tried and tested method in Norway. The state owned Norwegian Investment Fund for Developing Countries (Norfund) was established precisely on the premises that productive, private sector initiatives were essential for development. Norfund will soon celebrate its 15th year of operations, during which time it has seen its annual capital contribution from the government increase almost six fold, from NOK175 million in 1998 to NOK1 billion (approximately US\$166.5 million) in 2011. The government has also asked Norfund to offer softer loans for direct investments carrying more risk in the least developed countries (LDCs), increasing the opportunities that the fund has in being a co-investor in business projects in LDCs (Norwegian Government, 2010). This is a testament to growing political support for the 'business of aid' and of the government's willingness to use business solutions actively in achieving international development.

The influence of government on corporate behaviour cannot be ignored (Fox et al, 2002; Midttun, 2005; Albareda et al, 2007, 2008). Governments have a significant impact on company structures and strategies simply by their context defining power, as business organizations "reflect the differing societies and polities within which they operate [and can become] isomorphic with dominant institutions such as government” (Pearce et al, 2009:509). Looking at the role played by governments in CSR over the last decade, it seems that despite diverse industrial and political traditions there is a "common understanding and perception of the CSR concept" in public agendas (Albareda et al 2008). Divergences occur when applying the concept itself to the specific make-up of each national economy, but even here government action ranges within a limited set of roles mandating (minimum standards), facilitating (creating incentives and framework conditions), partnering (multi stakeholder engagement) and endorsing (publicity) - which can be combined in various manners (Fox et al, 2002). States undoubtedly play crucial roles for the definition and application of CSR as a tool for international development, in their tripartite position of owners, regulators and international development actors (Vogel, 2005; Newell \& Frynas, 2007). However, despite state influence at international level through participation in international forums and organizations, the impact at domestic level through ownership and regulation is more striking (Albareda et al 2007, 2008; Fox et al, 2002; Ghazali, 2007; Gjølberg, 2011; Graves \& Waddock, 1994; Lee, 2009; Li \& Zhang, 2010; Midttun, 2005; Prado-Lorenzo et al, 2009). It is these two factors that will be considered here.

While the extent of government influence varies, ownership is likely to increase the extent to which governments can, if they wish, interfere in business. Ownership seems to matter when choosing to pursue and report CSR activities (Graves \& Waddock, 1994; Ghazali, 2007; Prado-Lorenzo et al, 2009). CSR disclosure seems to be triggered by two different aspects: entrenchment or information effect. In the first case, "information disclosed 
will mainly reflect the interests of the dominant stockholder”, whereas in the second case information revealed will be limited according to the company's interest in making information available to its competitors (Prado-Lorenzo et al, 2009:97). In both cases the flow of information made publicly available is carefully managed in order to support the company's image and competitiveness, as well as that of its dominant stockholder. Analyzing the CSR reports of Malaysian companies, Ghazali (2007) observes that government ownership was positively associated with a higher degree of CSR disclosure. Evidence from China indicates that state owned companies were generally more likely to report on CSR than private or joint venture corporations due to their political links and different social accountability structures (Li \& Zhang, 2010). It would therefore seem that the state as a dominant owner is in a position to influence to a large extent the flow of information from its companies in a way that benefits its image the most.

Government documents detailing the state's ownership policy offer some insight into how public CSR policies and development cooperation policies may permeate the business sector (White Paper, 2006, 2011). The White Papers were designed to clarify the government's stance on various matters related to the state owned sector, including the objectives and organization of state ownership and a set of principles for good ownership and corporate governance. The latest describes how the State envisions its role as strategic owner, emphasising its ability "to follow up and influence the companies through both governance and dialogue" (White Paper, 2011:59). The report goes further, stating how "it must be assumed that, because the State is such a major shareholder in the companies with direct ownership, the State's expressly stated expectations will be accorded considerable weight by the companies" (Ibid.). These confident assessments of the state influence over its companies indicate that ownership represents an important tool the government holds and uses in order to promote its agenda with the corporate sector in Norway.

The reports also touched upon the issue of CSR, mentioning that "companies in which the State is a shareholder should take the lead in social responsibility", specifically protecting the environment and ensuring sound social conditions globally and locally (White Paper, 2006:30). If the government were not to assume this responsibility for the companies it owns, the White Paper argued, then the state's legitimacy as a legislator and in matters concerning foreign policy could be at risk. In other terms, strong CSR efforts are expected by the state-owned companies. However, it appears that the government adheres to an instrumental approach to CSR. The report mentions that the government believes that embracing CSR will "promote the profitability of the companies [...] whilst at the same time ensuring that the operations of the companies are perceived as ethically reasonable" (White Paper, 2011:60). Furthermore, it is revealed that "priorities linked to the competitiveness of the companies will therefore sometimes be necessary in order to safeguard the State's ownership in the best possible way" (Ibid.), thus subordinating responsibility to business values. The commercial drive seems therefore to have permeated even the Norwegian government's agenda and it is puzzling to witness its drive for stronger CSR commitments from companies when it seems "to prioritise profit at the cost of social welfare" (Morsing, 2011:711). Thus we might ask whether lack of results is a consequence of the trade-offs between CSR and competitiveness.

Second, CSR seems to be perceived as a limited instrument of corporate governance which cannot replace hard regulation. As mentioned earlier CSR is originally a voluntary, "non-authoritative self-regulatory approach" (Midttun, 2005:166) which some have interpreted as putting CSR firmly beyond the scope of legislative and formal regulations. Governments prefer the voluntary approach based on "the perception that businesses need to be allowed to develop new practices before regulation becomes appropriate, and regulation is seen as a stifling innovation" (Albareda et al 2008:360). However, initiatives created on a voluntary basis often evolve into soft law institutions; there are also examples of voluntary codes and international treaties being replaced by legislation after successful lawsuits (Gjølberg, 2011; Vogel, 2005). Such evolutions are more common in specific industries or among high profile companies that are under constant media and public scrutiny. Therefore hard law proponents point out to the need to set minimum standards that can effect substantial changes across the entire business environment.

In Norway, the government has so favoured proposing guidelines for CSR reporting. At the same time, however, it recognises the existence of limits on "what can and should be covered by the corporate governance of state-owned companies", supporting a role for "other public sector and general instruments, such as legislation, which are better suited to safeguarding [social responsibility] considerations" (White Paper, 2011:60). Norwegian companies also appear to be sceptical about the potential of CSR to replace public regulation and in general most would agree to a balance between voluntary and mandatory rules, operating within a well functioning public sphere (Gjølberg, 2011). Both sides invoke the argument of legislation as the fairest way of ensuring competition and a level playing field for companies. Therefore it seems that the Norwegian government 
is trying to maintain, and perhaps strengthen, its influence over certain areas of public interest, while at the same time allowing and encouraging businesses to become involved at different levels and within different sectors in social welfare. We have found no evidence suggesting that the fact that the state being a large shareholder has had any bearing on the CSR reporting of Norwegian TNC's. The Norwegian state as a large shareholder is simultaneously profit maximizing in its motives. If Norwegian companies are supposed to "do-good" in developing countries it might have severe influence on their ability to compete in the global markets.

In sum, it appears that in Norway the state has significant influence over the business sector thanks to significant state ownership, concentrated industrial structures and strong public sector policies. This enables a unique position for the Norwegian government to affect general corporate behaviour. In general larger firms are setting the agenda for CSR profiling and codes of conduct, thus influencing non-state owned companies. Norwegian companies seem to be doing particularly well in implementing CSR and are disproportionately represented in international CSR performance indexes. Both the state and the companies seem mindful to present an image that reflects positively upon Norway and is in accordance to the country's foreign policy goals. For now the state has not pushed its influence into hard regulation, and it may be that the link between government and corporate interests may affect development cooperation and CSR policies in more than one way. The Norwegian case is interesting due to the many similarities with other Nordic countries, but is more distinctive considering the large influence of the state. In general this analysis find that Nordic countries wants more government lead regulations and have little faith in self-regulations as a means of improving social end environmental performance (Gjølberg 2011). Competitiveness and branding are still the main reasons for strong CSR commitment whether the state is a shareholder or not.

\section{Transferring Agendas? The Government - Business Link in Norway}

Norwegian companies are rated among the best performers in terms of CSR. The Norwegian government too boasts one of the 'cleanest' development cooperation agendas. This study started from the twin observations of higher state involvement in CSR and of the involvement of profit-oriented organizations in problems related to international development. The goal was to determine how state and private agendas would interact at the intersection of CSR and development cooperation, under the assumption that a strong state, such as the Norwegian one, would influence the CSR debate. After exploring several problems related to CSR as a concept, its translation in Norway and the general arguments for and against it as a development tool, the previous section investigated the state's influence via ownership and regulation. This section provides some additional points for discussion based on the ideas previously exposed and propose some tentative areas for further research.

\section{Are Norwegian Companies that Much Better?}

At a first glance Norwegian companies appear to excel in social and environmental action, based on their inclusion in results-based CSR indexes. Their performance may be explained by the long tradition of upholding high social and environmental standards, arising from the particular configuration of social, economic and political forces in Norway. However, the previous analysis points out to a number of factors that may undermine this overly positive image.

First, CSR remains a contested concept the progress of which is difficult to monitor and evaluate. The CSR indexes used today to appraise corporate practices offer some means of evaluation and scrutiny, for some companies, in some sectors. However, they cannot serve as effective instruments of accountability. Second, the current debates related to CSR continue to develop along the lines of the instrumental approach. This may have contributed to the ingraining of business values into the CSR agenda, marginalizing alternative perspectives.

Therefore, if Norwegian companies are considered among the best according to the currently flawed standards, does it make them best practice examples? There is little investigation into the actual development effects of CSR programs. Arguably, a company's contribution to poverty reduction and development is more easily tracked in the number of people employed, the amount of taxes paid and so forth. Value-based goals related to the transfer of good governance practices or human rights principles are difficult to assess. Investigating the links between business-as-usual practices, CSR activities and development, would perhaps help improve our knowledge of the achievements and shortcomings of current corporate practices in developing countries.

\section{Where does the State Stand in Respect to CSR?}

Despite being criticised for not taking a firm stance on CSR in its 2009 White Paper, the government appears more than ever conscious of the impact Norwegian companies can have on the country's reputation. The analysis in this paper seems to indicate that the government is willing and able to use its position as strategic shareholder to ensure that CSR reporting reflects positively upon Norway's international image. As a stakeholder, both in its 
position as owner and as a regulator, the Norwegian government holds significant influence over its companies. Thus, in the case of Norway it does not seem surprising that companies with dominant state ownership strive to abide by public regulation, participate in international CSR initiatives and generally seem to do well in terms of social and environmental responsibility.

Norwegian TNCs' stellar performance is based on appraisals that do not put poverty reduction or other measurable development goals at the core of CSR initiatives (Blowfield, 2005; Jenkins, 2005; Margolis \& Walsh, 2003). Most of the data disclosed in Norwegian CSR reports is in accordance with mainstream CSR guidelines, such as the OECD Guidelines for Multinational Companies or the UN Global Compact. It seems unlikely that the government is infusing new values into the CSR debate. On the contrary, as Morsing (2011) postulates, it seems that in recent years the Norwegian government has become more sensitive to the commercial goals of its TNCs. It is not clear yet how this might affect the efficiency of Norwegian CSR programs. Therefore, it would be interesting to explore the commitments made by Norwegian TNCs in their CSR reports over the long term, and assess their results. This would hopefully help determine to what extent CSR is merely a cosmetic exercise mirroring societal expectations and to what extent it is relevant for a company and for the communities where it is involved.

Another interesting finding is the apparent agreement between businesses and governments on the limits of CSR and on the necessity of a well functioning public sector with hard regulation in place. As pointed out by previous studies, businesses that perform at or above the standards set internationally for social and environmental responsibility actually have a strong interest in the establishment of hard rules for their respective fields. By supporting stricter regulation internationally they benefit from a level playing field and perhaps even a competitive advantage over their competitors. It would be interesting therefore to see if and how corporate interests affect the government policies in this respect. While governments influence the business environment through regulation and the set up of public services they are in turn influenced by their links to corporations. The power of corporate interests over public policy cannot be overlooked, and the government's development cooperation program and its continuous support to Norwegian investment in developing countries can also be construed as a way to support the internationalization of Norwegian businesses.

Given the closely woven ties between state, corporations and civil society actors, can their interaction in the public debate result in genuine progress for the CSR agenda? This question is all the more important considering the Norwegian consensual approach to problem solving and the country's reputation of being a 'turtle', a laggard in terms of executing public reforms and implementing change (Olsen, 1996). If this pattern remains unchanged it may undercut the benefits of multi-stakeholder dialogues, namely the potential to challenge the status quo of underlying values and frameworks of the development and CSR agendas.

\section{CSR and International Development - A Balance or a Compromise?}

Paradoxically, it might appear that both the CSR and national development agendas are falling short of their promises. Are the goals and values exposed in the Norwegian discourse perhaps not adequate for furthering development? The answer is no. Without doubt most people desire to live without repression and discrimination, prefer peace to war, and enjoy a clean and healthy environment. However, the fact that there is still significant resistance to what seem to be noble initiatives cannot be attributed solely to corporate greediness or the malevolent intentions of interest groups. Most disagreements emerge from priority differences between the urgent needs of today, versus the desirable outlook for tomorrow. For instance, the Norwegian emphasis on what are arguably noble and desirable outcomes - peace, the respect of human rights, clean energy and the environment - may not match the development priorities identified by developing countries themselves. Acknowledging this basic fact seems crucial for opening up the development and CSR discourses. It seems therefore paramount to search for a better balance between development and CSR agendas in favour of problems related to poverty, economic exclusion and lack of representation that often plague the poor.

In turn, this should also draw attention away from businesses' interaction with Western NGOs and governments and towards their interaction with the governments and societies in the countries where they operate. A company's willingness to do business will first and foremost depend on the domestic political, economic and social conditions of a potential host country. Also, as suggested in previous studies businesses may adapt to local conditions rather than impose their own CSR frameworks (Chapple \& Moon, 2005). It appears interesting to look more into how Western companies interact with local governments in order to develop, translate or improve/ restrict their CSR practices. 


\section{Concluding Remarks}

This study intended to explore how the state and corporations are balancing the international development agendas, by analysing the case of Norwegian CSR. The general research interest was to investigate the roles a strong government could play in the CSR debate, and whether there is any potential to link CSR to international development objectives. Thanks to its unique features Norway represented a good candidate for the investigation of the interplay between governments, corporations and civil society in influencing corporate and global governance. This study set out to explore governmental and corporate practices in Norway related to CSR and development cooperation. In doing so, we have found little support for our opening assumption that strong governmental support for CSR leads to a bias towards certain areas of corporate responsibility in state owned TNCs' practices.

Despite seemingly different agendas, the State and Norwegian corporations appear to share a similar goal - to communicate a positive image positive image of Norway internationally. The strong sway the government has over TNCs thanks to significant state ownership may reinforce their commitment CSR reporting. At the same time, both the government and TNCs seem to be in accord as to the limits of CSR on effecting widespread changes and the continued importance of the public sector and state regulation. Therefore, Norwegian stakeholders appear to agree on the main values which should be made public. There is little indication that the public discourse and the criticism of profit seeking ventures actually leads to a reassessment of the business case for CSR in Norway. On the contrary, the state seems particularly sensitive to its companies' profitability and competitiveness. The apparent alignment between the topics proposed in the state's development cooperation agenda and those in Norwegian companies' CSR reports do not represent conclusive proof of a transfer of agendas. Therefore, this study concludes that despite being among the best in terms of social and environmental performance by current standards, Norwegian TNCs do not see international development goals as part of their mandate. Hence, investigating the links between business-as-usual practices, CSR activities and development might increase awareness of the fundamental reassessment of values needed for CSR to become an effective governance tool in developing countries.

\section{References}

Albareda, L., Lozano, J., \& Ysa, T. (2007). Public policies on corporate social responsibility: The role of governments in Europe. Journal of Business Ethics, 74(4), 391-407. http://dx.doi.org/10.1007/s10551-007-9514-1

Albareda, L., Lozano, J., Tencati, A., Midttun, A., \& Perrini, F. (2008). The changing role of governments in corporate social responsibility: Drivers and responses. Business Ethics: A European Review, 17, 347-363. http://dx.doi.org/10.1111/j.1467-8608.2008.00539.x

Alm, K. (2007). Challenges to investment ethics in the Norwegian Petroleum Fund: A newspaper debate. Philosophica, 80, 21-43.

Amland, B. (1993). Bistand eller børs? Neringslivets rolle i norsk u-hjelp (“Assistance or stock? Industry's role in Norwegian development aid”). Oslo: Cappelen.

Baskin, J. (2006). Corporate responsibility in emerging markets. The Journal of Corporate Citizenship, 24(4), 29-47. http://dx.doi.org/10.9774/GLEAF.4700.2006.wi.00006

Blowfield, M. (2005). Corporate social responsibility: Reinventing the meaning of development? International Affairs, 81, 515-524. http://dx.doi.org/10.1111/j.1468-2346.2005.00466.x

Blowfield, M. (2007). Reasons to be cheerful? What we know about CSR's impact. Third World Quarterly, 28, 683-695. http://dx.doi.org/10.1080/01436590701336523

Carroll, A. B. (1999). Corporate social responsibility: Evolution of a definitional construct. Business and Society, 38, 268-295. http://dx.doi.org/10.1177/000765039903800303

Chapple, W., \& Moon, J. (2005). Corporate social responsibility (CSR) in Asia: A seven-country study of CSR web site reporting. Business and Society, 44, 415-441. http://dx.doi.org/10.1177/0007650305281658

Davis, K. (1973). The case for and against business assumption of social responsibilities. The Academy of Management Journal, 16, 312-322. http://dx.doi.org/10.2307/255331

De Geer, H., Borglund, T., \& Frostenson, M. (2009). Reconciling CSR with the role of the corporation in welfare states: The problematic Swedish example. Journal of Business Ethics, 89, 269-283. http://dx.doi.org/10.1007/s10551-010-0393-5 
Detomasi, D. A. (2007). 'The multinational corporation and global governance: modelling global public policy networks’. Journal of Business Ethics, 71, 321-334. http://dx.doi.org/10.1007/s10551-006-9141-2

Donaldson, T. (1996). Values in tension: Ethics away from home. Harvard Business Review, 74(5), 48-62

Fox, T., Ward, H., \& Howard, B. (2002). Public sector roles in strengthening corporate social responsibility: A baseline study. Washington, DC: World Bank.

Friedman, M. (1970). A Friedman Doctrine - The Social Responsibility of Business is to Increase its Profits. The New York Times Magazine, 32-33, 123-126.

Frynas, J. G. (2005). The false developmental promise of corporate social responsibility: Evidence from multinational oil companies. International Affairs, 81, 581-598. http://dx.doi.org/10.1111/j.1468-2346.2005.00470.x

Frynas, J. G. (2008). Corporate social responsibility and international development: Critical assessment. Corporate Governance, 16, 274-281. http://dx.doi.org/10.1111/j.1467-8683.2008.00691.x

Ghazali, N. A. M. (2007). Ownership structure and corporate social responsibility disclosure: Some Malaysian evidence. Corporate Governance, 7(3), 251-266. http://dx.doi.org/10.1108/14720700710756535

Gjølberg, M. (2010). Varieties of corporate social responsibility (CSR): CSR meets the Nordic Model. Regulation \& Governance, 4, 203-229. http://dx.doi.org/10.1111/j.1748-5991.2010.01080.x

Gjølberg, M. (2011). Explaining regulatory preferences: CSR, soft law or hard law? Insights form a survey of nordic pioneers in CSR. Business and Politics, 13(2), 1-33. http://dx.doi.org/10.2202/1469-3569.1351

Graves, S., \& Waddock, S. (1994). Institutional owners and corporate social performance. The Academy of Management Journal, 37, 1034-1046. Retrieved from: http://www.jstor.org/stable/256611

Habermas, J. (2001). The Postnational Constellation. Cambridge: MIT Press.

Henderson, D. (2001). The case against 'Corporate Social Responsibility'. Policy, 17(2), 28-33. Retrieved from: http://www.cis.org.au/images/stories/policy-magazine/2001-winter/2001-17-2-david-henderson.pdf

Jackson, R., \& Sørensen, G. (2003). Introduction to International Relations. Oxford: Oxford University Press.

Jenkins, R. (2005). Globalization, corporate social responsibility and poverty. International Affairs, 81, 525-540. http://dx.doi.org/10.1111/j.1468-2346.2005.00467.x

Kobrin, S. J. (2009). Private political authority and public responsibility: transnational politics, transnational firms and human rights. Business Ethics Quarterly, 19, 349-74.

Lee, M. D. P. (2009). Does ownership form matter for corporate social responsibility? A longitudinal comparison of environmental performance between public, private, and joint-venture firms. Business and Society Review, 114, 435-456. http://dx.doi.org/10.1111/j.1467-8594.2009.00349.x

Li, W., \& Zhang, R. (2010). Corporate social responsibility, ownership structure and political interference: Evidence from China. Journal of Business Ethics, 96, 631-645. http://dx.doi.org/10.1007/s10551-010-0488-z

Margolis, J. D., \& Walsh, J. P. (2003). Misery loves companies: rethinking social initiatives by business. Administrative Science Quarterly, 48, 268-305. http://dx.doi.org/10.2307/3556659

Matten, D., \& Moon, J. (2008). "Implicit" and "Explicit" CSR: A conceptual framework for a comparative understanding of corporate social responsibility. Academy of Management Review, 33, 404-424. Retrieved from: http://www6.carleton.ca/ces/ccms/wp-content/ccms-files/MattenMoon-in-AMR-2008.pdf

Matten, D. and Crane, A. (2005). Corporate citizenship: towards an extended theoretical conceptualization. Academy of Management Review, 30, 166-79. Retrieved from: http://www.jstor.org/stable/20159101

Mele, D. (2008). Business ethics: Europe versus America. Issues in Business Ethics (Leadership and Business Ethics), 25, 13-27. http://dx.doi.org/10.1007/978-1-4020-8429-4_2

Midttun, A. (2005). Realigning business, government and civil society. Corporate Governance, 5(3), 159-174. http://dx.doi.org/10.1108/14720700510604797

Mitchell, R. K., Agle, B. R., \& Wood, D. J. (1997). 'Toward a theory of stakeholder identification and salience: defining the principle of who and what really counts'. Academy of Management Review, 22, 853-86. Retrieved from: http://www.jstor.org/stable/259247 
Morsing, M. (2011). State-Owned Enterprises: A Corporatization of Governments? Management Communication Quarterly, 25(4), 710-717. http://dx.doi.org/10.1177/0893318911415600

Newell, P., \& Frynas, J. G. (2007). Beyond CSR? Business, poverty and social justice: An introduction. The World Quarterly, 28, 669-681. http://dx.doi.org/10.1080/01436590701336507

Norwegian Government. (2010). The Government's Ownership Report 2009. Norwegian Government, Ministry of Trade and Industry, Oslo. Retrieved October 12, 2011, from www.eierberetningen.no/2009/asset/ownership_report_2009.pdf

Norwegian Government. (2012). The Government’s Ownership Report 2011. Norwegian Government, Ministry of Trade and Industry, Oslo. Retrieved September 13, 2012, from www.eierberetningen.no/2011/asset/ownership_report_2011.pdf

OECD. (2007). Business for development: Fostering the private sector. OECD Development Center, OECD.

Okoye, A. (2009). Theorising corporate social responsibility as an essentially contested Concept: Is a definition necessary?. Journal of Business Ethics, 89, 613-627. http://dx.doi.org/10.1007/s10551-008-0021-9

Olsen, J. P. (1996). Norway: Slow learner or another triumph of the tortoise? In J. P. Olsen, \& B. G. Peters (Eds.), Lessons from experience: Experiential learning in administrative reforms in eight democracies (pp. 180-213). Oslo: Universitetsforlaget.

Pearce, J. L., Dibble, R., \& Klein, K. (2009). The effect of governments on management and organization. The Academy of Management Annals, 3, 503-541. http://dx.doi.org/10.1080/19416520903047541

Porter, M., \& Kramer, M. (2006). Strategy and society - The link between competitive advantage and corporate social responsibility. Harvard Business Review, 84(12), 78-92.

Prado-Lorenzo, J. M., Gallego-Alvarez, I., \& Garcia-Sanchez, I. (2009). Stakeholder engagement and corporate social responsibility reporting: The ownership structure effect. Corporate Social Responsibility and Environmental Management, 16, 94-107. http://dx.doi.org/10.1002/csr.189

Ramos, J. L. (2010). Norwegian White Paper on CSR: An overview of the preparation and the approval process. The Royal Norwegian Society for Development.

Scherer, A. G., \& Palazzo, G. (2007). Toward a political conception of corporate responsibility. Business and society seen from a Habermasian perspective. Academy of Management Review, 32, 1096-120. Retrieved from: http://www.jstor.org/stable/20159358

Scherer, A., \& Palazzo, G. (2011). The New Political Role of Business in a Globalized World: A Review of a New Perspective on CSR and its Implications for the Firm, Governance, and Democracy. Journal of Management Studies. 48(4), 899-931. http://dx.doi.org/10.1111/j.1467-6486.2010.00950.x

UNCTAD. (2011). World Investment Report 2011 - Non-equity modes on international production and development. New York/ Geneva: United Nations.

Vogel, D. (2005). The market for virtue: the potential and limits of corporate social responsibility. Washington D.C.: Brookings Institution Press.

Waddock, S., \& Graves, S. (1997). The corporate social performance - financial performance link. Strategic Management Journal, 18(4), 303-319.

Welle-Strand, A. (2008). Pride and prejudice - Business, aid and charity. Telekronikk: Emerging Markets in Telecommunications.

Welle-Strand, A., Dehli, P., Kimmestad, E., \& Torp, C. (2009). Private actors in the aid landscape: Mapping an emerging segment in Norwegian development aid. Retrieved September 12, 2011, from: www.bi.no/OsloFiles/MICRO/2009/Publications/2009.04.23AID.LANDSCAPE.AWS.pdf

White Paper. (1999). Report No. 21 to the Storting (1999-2000): Focus on human dignity - A plan of action for human rights. Retrieved October 11, 2011, from http://www.regjeringen.no/en/dep/ud/Documents/propositions-and-reports/Reports-to-the-Storting/1999200 0/report_no-21_to_the_storting_1999-2000/5/8/1.html?id=192613

White Paper. (2006). Report No. 13 to the Storting (2006-2007): An active and long-term state ownership. Retrieved September 21, 2010, from www.regjeringen.no/Rpub/STM/20062007/013EN/PDFS/STM200620070013000EN_PDFS.pdf 
White Paper. (2009a). Report No. 10 to the Storting (2008-2009): Corporate social responsibility in a global economy. $\quad$ Retrieved March 14, 2010, from http://www.regjeringen.no/pages/2203320/PDFS/STM200820090010000EN_PDFS.pdf

White Paper. (2009b). Report No. 13 to the Storting (2008-2009): Climate, conflict and capital. Retrieved September 21, 2010, from http://www.regjeringen.no/pages/2171591/PDFS/STM200820090013000EN_PDFS.pdf

White Paper. (2009c). Report No.15 to the Storting (2008-2009): Interests, responsibilities and possibilities The main features of Norwegian foreign policy. Retrieved November 22, 2011, from http://www.regjeringen.no/pages/14607054/PDFS/STM200820090015000EN_PDFS.pdf

White Paper. (2011). Report No. 13 to the Storting (2010-2011): Active ownership. Retrieved November 12, 2011, from http://www.regjeringen.no/pages/36076278/PDFS/STM201020110013000EN_PDFS.pdf

World Economic Forum (WEF). (2011). The Global Competitiveness Report 2011-2012. Geneva: World Economic Forum. Retrieved December 18, 2011, from http://www.weforum.org/reports/global-competitiveness-report-2011-2012

\section{Copyrights}

Copyright for this article is retained by the author(s), with first publication rights granted to the journal.

This is an open-access article distributed under the terms and conditions of the Creative Commons Attribution license (http://creativecommons.org/licenses/by/3.0/). 